\title{
Polifonía e hibridismo xenolóxico en Lapidario (2004) de Miguel-Anxo Murado
}

\author{
Polyphony and Genre Hybridism in Lapidario (2004) \\ by Miguel-Anxo Murado
}

\author{
Martín Veiga \\ University College Cork \\ Department of Spanish, Portuguese and Latin American Studies \\ m.veiga@ucc.ie
}

[recibido 06/11/2014, aceptado 31/01/2015]

\section{RESUMO}

Este artigo reflexiona sobre o epitafio como forma literaria mediante unha análise das principais diferenzas textuais e paratextuais que presentan Lapidario e o seu predecesor Lapidario dos heterodoxos, de Miguel-Anxo Murado. Tamén examina os complexos usos que no libro se dan da polifonía e o hibridismo xenolóxico como estratexias posmodernas que problematizan a lectura do texto en clave meramente poética.

PALABRAS CHAVE: Poesía galega, epitafios, polifonía, xéneros literarios.

\section{RESUMEN}

Este artículo reflexiona sobre el epitafio como forma literaria mediante un análisis de las principales diferencias textuales y paratextuales que presentan Lapidario y su predecesor Lapidario dos heterodoxos, de Miguel-Anxo Murado. También examina los complejos usos que en el libro se dan de la polifonía y el hibridismo genológico como estrategias postmodernas que problematizan la lectura del texto en clave meramente poética.

PALABRAS CLAVE: Poesía gallega, epitafios, polifonía, géneros literarios.

\section{ABSTRACT}

This article reflects on the epitaph as literary form by looking at the main textual and paratextual differences between Miguel-Anxo Murado's Lapidario and its predecessor Lapidario dos heterodoxos. It also examines the book's complex uses of polyphony and genre hybridism as postmodern strategies which problematize the reading of this text as merely a poetry collection.

KEY WORDS: Galician poetry, epitaphs, polyphony, literary genres.

Veiga, M. (2015): "Polifonía e hibridismo xenolóxico en Lapidario (2004) de Miguel-Anxo Murado", Madrygal (Madr.), 18, Núm. Especial: 147-157.

SUMARIO: 1. Introdución. 2. O epitafio como forma literaria. 3. Murado e os repertorios culturais: adiviñas, bestiarios, epitafios. 4. De Lapidario dos heterodoxos a Lapidario. 5. O hibridismo xenolóxico. 6. Polifonía e poesía dramática. 7. Conclusión. 8. Referencias bibliográficas. 


\section{INTRODUCIÓN}

En 2004 o escritor e xornalista Miguel-Anxo Murado (Lugo, 1965) publicou Lapidario, obra que presenta unha serie de epitafios poéticos de personaxes diversas, de todas as épocas e lugares, pertencentes principalmente ao ámbito da literatura e do pensamento. Porén, esta obra non é totalmente orixinal e nova, xa que se trata dunha versión revisada e moi ampliada do libro de poemas que, baixo o título de Lapidario dos heterodoxos, publicara Murado en 1990, tras acadar con el o accésit do lamentabelmente desaparecido Premio Esquío de Poesía en lingua galega, na súa novena convocatoria. Entre ambas as dúas edicións existen diferenzas substanciais, non só relativas ao contido textual, senón tamén con respecto aos seus paratextos, que nesta obra ofrecen especial interese. Logo dunhas breves consideracións sobre o epitafio, xénero que coñece singular presenza na literatura universal e tamén na galega, este artigo dá conta das citadas diferenzas entre as dúas versións e pescuda nas fontes literarias da obra. Ademais, analiza os mecanismos mediante os cales, baixo unha aparencia de homoxeneidade xenérica, os diversos textos que integran Lapidario incorporan compoñentes líricos, dramáticos, narrativos e mesmo elementos da escrita académica ou enciclopédica. Esta concorrencia, de orixe posmoderna, problematiza a súa adscrición ao xénero poético e proporciónalle á obra un carácter híbrido e aberto. De por parte, o artigo examina tamén a convivencia polifónica, nas páxinas do libro, de polo menos tres voces ou instancias enunciativas: a das personaxes que brindan en primeira persoa os seus epitafios; a do falante lírico, que por veces actúa como un verdadeiro autor implícito; e a dun compilador que matiza, complementa e apostila os testemuños ofrecidos.

\section{O EPITAFIO COMO FORMA LITE- RARIA}

Malia que a práctica de dispoñer unha inscrición sobre a tumba xa se levase a cabo de xeito invocatorio e instrumental no Antigo Exipto, berce da escrita funeraria en Occidente, o epitafio como xénero literario ten a súa orixe na Antigüidade clásica. Así se indica na entrada correspondente a esta voz no Dicionario de termos literarios elaborado polo Equipo Glifo (2003: 146): "A súa inclusión entre as categorías literarias produciuse na Antigüidade clásica coa denominación polos tratadistas latinos de laudatio funebris". Segundo define este dicionario, o epitafio, que pode estar escrito en prosa ou en verso, convida á lembranza dun ser desaparecido e propón unha reflexión sobre as súas calidades ou sobre a morte en xeral. Ademais, en canto aos temas dos que se ocupa, relaciónase cos tópicos literarios temporais como o ubi sunt, o contemptus mundi, o memento mori e o carpe diem, que amosan a condición efémera e transitoria da vida humana, aínda que exista tamén un epitafio de tipo burlesco ou satírico. Finalmente, o dicionario aclara que, desde un punto de vista xenolóxico, o epitafio mantén un vínculo estreito con formas como o pranto e a necrolóxica, e sinala a brevidade como unha das súas características principais, o que propiciou que se convertese "nun dos campos máis atractivos para a experimentación estilística orientada ó conceptismo e a agudeza" (Equipo Glifo 2003: 146).

No contexto da poesía europea moderna, William Wordsworth publicou en 1810 unha interesante colección de ensaios titulada Essays upon Epitaphs, reflexión de carácter metafísico sobre a morte que vencella o acto de morrer co acto da escrita (Hall 2001: 658). Nesta obra, Wordsworth designa a voz epitáfica como unha ficción de presenza segundo a cal a imaxinación xera unha interposición sombriza, é dicir, unha inscrición que une o mundo dos vivos e o dos mortos. As conclusións ás que chega no devir da argumentación pódense aplicar mesmamente á súa poesía, e autores como Ferguson (1977), Hall (2001) e Mills-Courts (1990) interpretaron os ensaios sobre os epitafios de Wordsworth como parte esencial da súa teoría poética, desenvolvendo deste modo unha exéxese da súa poesía en virtude da estreita relación que esta mantén coa noción de epitafio e co seu significado.

No ámbito da literatura galega contemporánea, en particular na poesía de posguerra, o epitafio coñeceu manifestacións diversas, 
entre as que destacan as propostas de índole culturalista de Álvaro Cunqueiro. O autor mindoniense escribiu poemas elexíacos nos que emprega a forma epitáfica de maneira semellante á que Murado emprega en Lapidario, polo que poemas de Cunqueiro como "Epitafio a Noriega Varela", "Un epitafio para Lord Dunsany" e "Lord Dunsany/Epitafio" ben poden actuar como antecedentes dos textos de Murado, pois comparten rexistro e intencións, ademais de posuíren trazos formais e estilísticos similares. Pola súa banda, Aquilino Iglesia Alvariño cultivou formas poéticas afíns, especialmente en Nenias, obra publicada en 1961 na que, como explicou Rodríguez Gómez, o autor lle rende homenaxe a "unha galería de personaxes-artistas" que foron "alma formadora da personalidade poética do autor" (Iglesia Alvariño 1991: 60), entre as que figuran poetas pertencentes a tradicións tan diferentes como Catulo, Luís Amado Carballo, Hölderlin e Carles Riba. Emporiso, Nenias carece dunha característica que si figura nas obras de Cunqueiro e de Murado como parte integrante fundamental do seu concepto de epitafio: o distanciamento irónico e o sentido do humor. Iglesia Alvariño substitúe estes elementos por un ton grave e desolado propio dos cantos fúnebres que conforman a súa obra. Outro poemario que experimentou co epitafio como forma literaria é Cimenterio privado, que Celso Emilio Ferreiro publicou en 1973. Esta obra presenta o epitafio como forma poética que posibilita un tratamento satírico e burlesco da realidade ou de certos tipos sociais. A diferenza dos libros comentados anteriormente, Cimenterio privado non acolle os epitafios de personaxes concretas, senón de tipos humanos estereotipados tales como "O petrucio", "O poeta esquisito", "O optimista", "O treidor", "O sentimental", etc. Esta particularidade proporciónalle á obra carácter universal e un marcado contido de crítica social que o autor nunca procurou evitar.

\section{MURADO E OS REPERTORIOS CUL- TURAIS: ADIVIÑAS, BESTIARIOS, EPI- TAFIOS}

A natureza epigramática do epitafio é un aspecto que Murado explota en Lapidario con intencións nalgúns casos humorísticas e noutros, porén, con afán sintetizador. Un procedemento semellante empregárao xa o autor na súa primeira entrega lírica, Bestiario dos descontentos, na que propoñía unha poética a medio camiño entre o lúdico e o transcendente, e empregaba como recurso a forma da adiviña. Desde o punto de vista da súa definición xenolóxica, no "Proemio" a esta obra o autor recoñecía a pertenza do libro ao xénero dos bestiarios, mais tamén afirmaba o seguinte: "Estes animais, e cousas contempladas como animais, teñen -coma os monstros máis evidentes- corpo de adiviña, xénero popular" (Murado 1985: sen páxina). En efecto, á parte da maior ou menor lonxitude dos poemas, o xeito en que os contidos da obra se van artellando invoca o das adiviñas, mesmo coa súa resposta ou solución, elemento paratextual que actúa como se fose o título do poema, fornecida entre parénteses ao final do texto ${ }^{1}$ :

Disposto a intentar a felicidade crerei por enésima vez que ó remate da viaxe non ten por que estar, necesariamente, esa absurda morte de sal e naufraxio.

(O río)

Mirádeme ben, fixádevos; son o que estabades mirando antes de me ver e tamén o que agora mirades.

(A realidade)

Estes dous libros, os únicos poemarios que Murado publicou ata o día de hoxe, comparten un profundo carácter narrativo. Bestiario dos descontentos explora os límites formais entre a narrativa e a poesía, polo que Xosé M. Eyré o incluíu nun estudo sobre a narrativa galega actual, pese a incidir na súa indefinición

\footnotetext{
${ }^{1} \mathrm{O}$ libro non ten paxinación pero os poemas están numerados. Os textos citados corresponden, respectivamente, aos números 16 e 24 . A obra conta coas suxestivas ilustracións de Antonio Murado, irmán do autor, que dialogan na páxina cos poemas-adiviñas.
} 
xenérica e na súa resistencia á catalogación: "(Na obra) a realidade interiorízase, fragmentada, como un xogo de incomprensións onde o mundo lírico en que nacen e se insiren leva tanto a pensar en poesía como en prosa" (1996: 1567). Pola súa banda, Lapidario é un libro de poesía narrativa que, segundo declaracións do propio autor, naceu como obra en prosa e logo virou cara ao xénero poético: "Comecei este libro como libro en prosa, seguindo a liña do Bestiario dos descontentos. Logo decidín convertelo en libro de poesía" (www.miguelmurado.com).

Ademais, teñen en común unha idéntica vontade de unidade, propiciada en ambos os dous casos por un elemento cohesivo que forma parte esencial e incluso definitoria das propias obras e que obriga a lelas desde unha posición determinada, cunhas expectativas de xénero previamente estabelecidas e ben asentadas nos repertorios culturais: dunha parte, o bestiario, de longa tradición literaria e artística; da outra, o epitafio, forma que Murado reinventa e reformula ${ }^{2}$.

\section{DE LAPIDARIO DOS HETERODOXOS A LAPIDARIO}

Entre Lapidario dos heterodoxos, a versión inicial de 1990, e o Lapidario de 2004 atópanse, como xa se indicou, notábeis diferenzas textuais e paratextuais. Respecto ás mudanzas de carácter estritamente textual, aos 34 poemas da primeira edición engádenselles na segunda 24 composicións máis e desaparece o epitafio que pechaba a colección en 1990, un texto inzado de ironía dedicado ao escritor norteamericano Horatio Alger Jr., que a seguir se reproduce ${ }^{3}$ :
(Aqui non hai lápida escrita. O lector, por moito que a busca, non a encontra. E iso que correspondería a un autor que fixo centos de epitafios para si mesmo.

Horatio Alger jr. - pois del se trata- escribia historias de rapaces que ascendian da miseria á opulencia. Mentres, en cambio, el mesmo pasaba da opulencia á miseria.

Logo púxose tolo e empezou a recorrer Broadway con capa e unha parruca loira predicando a Biblia. Cando volvía á casa era cando escribía epitafios para si. Considérase que o mellor é aquel que di:

"Aquí xaz un bo rapaz

que aproveitou a súa vida

mentres a tivo".

Morreu dun catarro, e ademais un día de Xullo). (Murado 1990: 56)

Aínda que este é o único dos poemas do primeiro libro que non recolle a segunda edición, moitos outros epitafios foron suxeitos a pequenas mudanzas ou leves correccións de carácter ortográfico ou léxico. En concreto, os cambios consisten maiormente na revisión de castelanismos, actualizacións da normativa ortográfica, alteracións na puntuación e incorporación de elementos que tentan aclarar posíbeis sentidos escuros no texto inicial.

Neste sentido, a frecuente achega de nexos conxuntivos e doutros conectores lóxicos nalgúns versos incrementa a claridade do texto, pero ten como consecuencia a perda de parte da súa indefinición e carga suxestiva. Ademais, a orde de aparición dos poemas no libro tamén se modificou na nova edición. Non obstante, se se exceptúan obviamente os poemas engadidos ao novo libro, a maioría dos cambios de tipo textual non altera substancialmente o

\footnotetext{
${ }^{2}$ Neste sentido, resultan de interese as reflexións de Arturo Casas arredor do xénero literario, nas que propón o caso de Lapidario dos heterodoxos como paradigma de obra que compromete o lector a descifrar os seus signos desde unha perspectiva dada, que el delimita "como unha analecta accidental de epitafios moi marcada por un requerimento anamórfico" (Casas 1998: 669).

${ }^{3}$ Horatio Alger Jr. (1832-1899) foi un escritor moi prolífico de penny dreadfuls, un tipo de novela popular, barata e publicada por entregas, que acadou moito éxito entre finais do século XIX e comezos do XX, tanto nos Estados Unidos como no Reino Unido.
} 
contido da obra ou, cando menos, a súa esencia e intención ${ }^{4}$.

En canto aos compoñentes do corpo paratextual, as diferenzas comezan xa no propio título, aspecto ao que se referiu o autor nunhas declaracións efectuadas canda a publicación da segunda versión: "Agora prefiro os títulos máis curtos, máis sinxelos, pero tamén quería ampliar o número de personaxes que pasan polo libro" (Franco 2004: 54). Ademais, Lapidario dos heterodoxos iniciábase cun prólogo da autoría do poeta lugués Carlos Casanova, que tampouco aparece na versión máis actual, substituído desta volta por un limiar aclaratorio e informativo do propio Murado. Naquelas liñas, Casanova aludía brevemente á cuestión das voces, é dicir, á importancia no libro do recurso á polifonía, ao considerar a obra como "unha especie de foxa común na que o escritor-como un medium consumado, como un experto ventrílocuo- convoca ós seus vellos amigos (os mellores, os amigos das súas lecturas lexendarias) e fai que falen coa súa propia voz (a del, a deles)" (Murado 1990: 10).

A cesión da voz, tema que logo se examinará máis polo miúdo, trátase, desde logo, dun trazo propio do xénero, como apuntou Hall en relación co libro de Wordsworth anteriormente citado:

The epitaphic model reveals how the funeral biographer actually ventriloquizes his own voice to impersonate the figure resting beneath the tombstone in a tender fiction of representation (...) The poet as ventriloquist bears the dead, at once, by giving them imaginative life from beyond the grave and eulogizing them in an act of communal sympathy and self-consolation. (Hall 2001: 660)
No seu limiar, Casanova sinalaba tamén que eran os malditos, os xenios, os suicidas, os heterodoxos, en fin, as personaxes que o poeta salvaba do esquecemento iluminando cos epitafios "a cruel paradoxa dos seus destinos", e engadía un dato de particular interese referido á continuidade dun proxecto que non se pechaba coa publicación da obra, senón que ficaba aberto á súa ampliación, o que de feito aconteceu: "O poeta (...) non cesará de alimentar o 'continuum' do lapidario, engadirá á súa nómina de ilustres heterodoxos máis personaxes que boten novas luces ó noso intelecto; que non cese a policromía das derrotas máis insignes" (Murado 1990: 11). Así o fixo o autor, que seguiu traballando no libro por espazo de varios anos, non por un desexo perfeccionista, como el mesmo aclarou, senón pola entidade mesma da obra, que se caracteriza precisamente por estar aberta á continuidade (Murado 2004: 9) .

Outro elemento paratextual que non figura na nova versión é un conxunto de máximas de orixe diversa, en letras maiúsculas e en linguas diferentes que pechaba cada un dos epitafios na primeira obra, actuando á maneira de inscricións nunha campa que podía ser a páxina mesma. Todas elas estaban relacionadas coa morte, co paso do tempo e mais coa condición efémera da vida humana, e complementaban o sentido do poema que acompañaban. Estas sentenzas viñan traducidas nun glosario que se incluía ao final do libro e que tampouco se reproduce no novo lapidario. No seu lugar, aparecen doce páxinas de notas bio-bibliográficas correspondentes a cada personaxe (a cada poema), que proporcionan, ademais, explicacións ou aclaracións a alusións ou puntos escuros do

${ }^{4}$ En canto ás alteracións textuais, no epitafio dedicado a Jonathan Swift dáse un cambio rechamante con respecto ao sentido orixinal do poema. Compárense estes versos en ambas as dúas versións: “Que todos os meus libros sexan dados ás Academias./ Que todas as miñas propiedades sexan dadas ó Manicomio" (Murado 1990: 32); “Que todas as miñas propiedades sexan dadas ás Academias./ Que todos os meus libros sexan dados ao Manicomio" (Murado 2004: 26).

${ }^{5}$ En adiante, todas as referencias a Lapidario corresponden a esta edición e presentan simplemente o número de páxina entre parénteses inmediatamente a seguir a mención correspondente. 
texto $^{6}$. Murado xustificou no prólogo a súa decisión de incorporar as notas declarando que estas representaban un esforzo para conseguir que o libro chegase a un maior número de lectores e rematou cunha afirmación que revela a importancia que lle concede á presenza das notas na obra: "Penso que as notas académicas a un libro presentan ás veces unha fría beleza. No Lapidario, non son un apéndice ao libro, senón que forman un todo con el" (11). A pesar de que a inclusión, por parte do autor, de notas nos libros de poemas sexa desde logo unha práctica inusual, existen precedentes ilustres na literatura en lingua inglesa, como Mercian Hymns, de Geoffrey Hill, ou The Waste Land, de T. S. Eliot. Na obra eliotiana, as notas eruditas, inicialmente encargadas polo editor para lle engadir páxinas ao orixinal e así xustificar a súa publicación como libro, pasaron co tempo a formar parte intrínseca do propio texto poético. No caso de Lapidario, as notas bríndanlle ao libro unha vontade de didactismo que o achega ao rexistro da escrita académica ou incluso ao formato da enciclopedia, un xénero polo que Murado se confesa apaixonado (10). A aparencia de academicismo da obra refórzase mediante a maneira en que son presentadas as personaxes ás que se dedica cada epitafio. Mentres os poemas de Lapidario dos heterodoxos non levaban título e o lector debía deducir do contido textual o destinatario ou protagonista do poema, nas composicións da segunda versión da obra o nome dos destinatarios facilítase tal como se podería atopar nunha enciclopedia ou nun dicionario biográfico, é dicir, o apelido seguido polo nome: "Pimentel, Luís" (32), "Chatterton, Thomas" (48), "France, Marie de" (75-76), etc.

A actual edición conserva as dúas citas que encabezaban o libro en 1990, tomadas de senllos poemas de Dylan Thomas ("And death shall have no dominion") e de François Villon
(“Mais où sont les neiges d'antan?"). As epígrafes introducen os temas principais da obra, que se resumen de xeito emblemático na forma epitáfica: a presenza da morte e o transcorrer implacábel do tempo. En ambas as dúas edicións figura tamén un poema introdutorio que serve como presentación dos contidos da obra e que actúa ademais como declaración das súas intencións temáticas:

Direi unha pregaria polos que están baixo terra, polos que vagan convertidos en cinza, polos que nin se sabe onde están.

Falarei dos que morreron de soidade, dos que morreron con violencia, dos que morreron de propia man. (...)

Vou narrar o infortunio

das xentes do pasado, e referirei a condición do home e a súa estrela mal cifrada.

Hoxe, a compaixón é o meu tema. (15-16)

Este texto vai pola súa vez precedido por unha epígrafe que reproduce os tres primeiros versos do poema inicial da Spoon River Anthology, que o estadounidense Edgar Lee Masters publicou en 1915 e que lle serve de modelo literario a Lapidario. O poema de $\mathrm{Mu}-$ rado claramente propón un diálogo intertextual coa composición de Lee Masters, que se titula "The Hill" e presenta algunhas das personaxes e situacións que poboan as páxinas da obra, polo que exerce un papel de pórtico ou limiar. Velaquí os versos de Lee Masters que forman a epígrafe que cita Murado no seu poema: "Where are Elmer, Herman, Bert, Tom and Charley,/ The weak of will, the strong of arm, the clown, the boozer, the fighter?/ All, all, are sleeping on the hill". A Spoon River Anthology, libro, por certo, inspirado nun clásico da literatura epitáfica como é a Antoloxía grega, recolle máis de douscentos poemas

${ }^{6} \mathrm{O}$ libro ofrece tamén información complementaria entre parénteses ao final de moitos dos poemas, a xeito de notas a pé de páxina, como no caso do epitafio de Leiras Pulpeiro: "(Nos xornais La Voz de la Verdad e Norte de Galicia non se dá información sobre a morte do médico poeta nin se admiten esquelas)" (37), ou no de Yasunari Kawabata: “(Y. K. foi Premio Nobel en 1968)" (78). 
escritos como epitafios dun cemiterio imaxinario situado no outeiro dunha vila tamén imaxinaria, tradicional e característica do Medio Oeste norteamericano, como explicou Alberto Girri, tradutor ao castelán dunha escolma de poemas desta obra (Lee Masters 1974: 8). O libro de Lee Masters constitúe, xa que logo, o antecedente literario máis obvio de Lapidario, e con el comparte elementos como o diálogo entre personaxes a través de distintos epitafios, que na obra do americano propicia o desenvolvemento de varias tramas narrativas internas e na de Murado conduce a intencionados anacronismos empregados como pretexto lúdico, como acontece tamén nalgúns poemas de Cunqueiro. Por caso, nun dos epitafios de $\mathrm{La}$ pidario, o poeta chinés Li Po lembra o tráxico destino de Ofelia, personaxe de Hamlet (30). Xa Murado advertiu no prólogo acerca da intencionalidade da presenza dos anacronismos, pois, asegura, as personaxes da obra viven fóra do tempo, no non-lugar da morte, na ucronía (10). Así e todo, para alén das posíbeis influencias literarias que sustentan o discurso poético da obra, Murado indicou que esta naceu da combinación de dous conceptos fundamentais: a biografía como metáfora da vida e a brevidade como forma. Segundo clarificou o autor, estas dúas nocións aparecen encarnadas nun xénero, como o epitafio, que xa estaba inventado, o que liberou o escritor da obriga da orixinalidade (9-10).

\section{O HIBRIDISMO XENOLÓXICO}

Lapidario integra, polo tanto, elementos poéticos, narrativos e tamén compoñentes propios da retórica académica ou enciclopédica mediante o uso da forma epitáfica e a presenza das notas. A fasquía narrativa da obra incrementouse na súa segunda versión por mor da achega de varios epitafios escritos directamente en prosa ou en prosa poética, algo que apenas ocorría na primeira edición. Así acontece cos epitafios dedicados a Sigismondo Malatesta (39-40), Walter Benjamin (46-47) e Raimon Llull (96), entre outros. Neste sentido, un dos textos, o dedicado ao poeta e monarca turco Babur (87-92), ocupa un total de tres páxinas e aparece explicitamente nomeado como "relato", o que problematiza a súa lectura como texto poético, mais tamén como epitafio en sentido estrito. Pero ademais de elementos claramente narrativos, a obra incorpora, como xa suxeriu o seu autor, aspectos característicos da escrita dramática:

Os personaxes aquí relacionados son aqueles que eu atopei -nas lapelas dos libros, nas entradas dos dicionarios biográficos- que querían dar un paso adiante e dicir algo. Porque é así como os imaxino neste libro: como un pequeno teatriño infantil onde unha pantasma -no dobre sentido de "espírito" e de "creación da fantasía"- dá un paso adiante e recita a súa parte. (10)

Algunhas das personaxes non só recitan a súa parte no escenario teatral que pretende simbolizar a obra, senón que mesmo dialogan con outras personaxes a través das páxinas e dos séculos, nun diálogo que segundo o autor non é sen máis un artificio, senón que existe, ou podería existir, nos seus libros (10). A proximidade de Lapidario a un texto de carácter dramático refórzase tamén mediante a utilización, en varios epitafios, de indicacións escénicas ao máis puro estilo teatral. Estas notas aparecen en letra cursiva e entre parénteses, ben para indicar acción ou ben para situar o espazo, como este exemplo do epitafio de Jan Potocki:

(Nunha pequena tenda de antigüidades, oculta nunha rúa da parte vella de Lodz, en Polonia. O anticuario, un tipo chosco e ruín, un pirata que fixo carreira de contrabandista primeiro e logo de delator, mostra unha peza a un turista). (41)

Esta breve aclaración vai seguida dun diálogo entre o anticuario e o turista, que ben podería ser unha escena tirada dunha peza teatral. Noutros casos, as didascalias indican outro tipo de detalles tales como o fondo musical da acción, como exemplifica o epitafio de Jean-Marie Colot D'Herbois: "(Soa de fondo 'La Carmagnole')" (43). Esta viraxe decidida cara ao narrativo e o teatral, nunha obra que xa na súa primeira edición contaba con algúns asomos formais destes eidos, quizais se poida explicar polo interese e dedicación crecentes de Murado, desde a publicación de Lapidario dos heterodoxos, pola narrativa curta, polo 
mundo do teatro e mais pola escrita de guións para cinema e televisión ${ }^{7}$.

Nun comento sobre Lapidario, Vicente Araguas observou a "confusión xenérica" e a "fusión" entre ficción e non ficción que se verifica nesta obra e, en xeral, na produción de Murado. Á parte de recomendar a lectura da obra, Araguas incidiu na versatilidade e na pluralidade da proposta literaria de Murado, a quen definiu como "un autor do máis peculiar -e brillante- que pode facer (non digo que faga isto necesariamente) prosa á hora da poesía e poesía á hora da prosa" (2005: 3). Desde unha perspectiva xenolóxica, polo tanto, baixo a aparencia de uniformidade que lle proporciona o recurso ao epitafio, Lapidario é unha obra híbrida, complexa, debido sobre todo á xustaposición e ao emprego simultáneo de estratexias formais e estilísticas pertencentes a xéneros distintos. En relación con este aspecto, o propio Murado salientou que a obra tenta "aportar algo aos xéneros e, neste caso, ao xénero dos epitafios" e emitiu valiosas reflexións arredor da indefinición xenérica da obra: "A poesía non ten por que ser só lírica, pode ser narrativa e pode, como neste caso, servir ao xénero biográfico" (Franco 2004: 54).

\section{POLIFONÍA E POESÍA DRAMÁTICA}

De por parte, nas páxinas da obra comparecen múltiples voces, nalgunhas ocasións concorrendo no mesmo poema. Primeiramente, a voz das personaxes, que brindan en primeira persoa os seus epitafios ou, como apunta o autor, dan un paso adiante no teatriño e recitan o seu papel. Araguas enxergou esta particularidade do texto, indicando que, na obra, Murado bota man dunha serie de autores "aos que fai falar en primeira persoa á hora de nos ceibar a súa mensaxe desde a cova" (2005: 3). En efecto, isto forma parte da convención do xénero epitáfico e, en xeral, de toda a poesía dramática, na que o autor implícito se esvaece e lles cede a voz ás súas personaxes. Así acontece nos monólogos dramáticos de Robert Browning, cuxa influencia resultou decisiva no desenvolvemento da poesía europea contemporánea, e nos que unha personaxe se confesa no poema. Nunha recensión á tradución ao castelán da antoloxía poética de Browning La licencia y el límite, Edgardo Dobry (2006: s. p.) aludiu á natureza teatral dos seus monólogos dramáticos, comparándoos con "esas tiradas en las que se lucían los mejores actores shakespearianos", pero soubo apreciar tamén a súa "textura narrativa", elementos os dous igualmente presentes de xeito evidente en Lapidario. A confesión en primeira persoa dunha personaxe prodúcese igualmente na serie de poemas de Cunqueiro que comezan polo sintagma "Eu son...", nos que personaxes mitolóxicas ou literarias como Danae, Edipo ou Paltiel se expresan coas súas propias voces. Este carácter dramático da poesía cunqueiriana albiscárono críticos como Forcadela (1996: 1072) e Rábade Villar, que manifestou ao respecto: "(Nestes poemas) o suxeito convértese nun 'eu ventrílocuo', que acolle tanto a reminiscencia implícita dunha primeira persoa máis ou menos próxima a unha figuración do autor como unha identidade ficcional" (2003: 81) ${ }^{8}$. En fin, aínda que fique fóra do obxecto deste artigo, semella aquí importante observar que a viraxe do lírico cara ao narrativo e dramático representa un trazo que, desenvolvido e sometido a diversas tensións discursivas propias da posmodernidade, encontra especial rendemento nalgunha da poesía galega máis actual, como estudou González Fernández (2001: 6) ${ }^{9}$.

\footnotetext{
${ }^{7}$ Desde 1990 publicou varios libros de relatos, como Memoria de derribos, Ruído. Relatos de guerra, Mércores de cinza e $O$ soño da febre. Ademais, foron publicadas e representadas as súas obras teatrais $A$ grande noite de Fiz e Historias peregrinas e tres guións cinematográficos da súa autoría recibiron o Premio Carlos Velo.

${ }^{8}$ Rábade Villar (2014) afondou nesta cuestión da poesía de Cunqueiro en relación co espazo e a xustiza.

${ }^{9}$ Pénsese, por caso, na rendibilidade do emprego de recursos narrativos e dramáticos en $m$-Talá, de Chus Pato, un poemario que se caracteriza pola polifonía e pola subversión das nocións tradicionais de xénero literario que representa.
} 
De xeito semellante ao que ocorre cos poemas de Browning e Cunqueiro, nos poemas de Lapidario o escritor actúa como medium ou ventrílocuo permitindo que as personaxes falen coa súa propia voz, como explicou Casanova. Pero cómpre lembrar que Casanova remata o seu argumento cunha estudada ambivalencia relativa á cuestión da polifonía no poemario, xa que salienta que Murado "convoca ós seus vellos amigos (...) e fai que falen coa súa propia voz (a del, a deles)" (Murado 1990: 10). Este breve comentario final, emporiso, ten importancia decisiva, pois parece deixar entender que a voz das personaxes e a voz do escritor se funden no seo dos textos, convértense nunha soa voz nos poemas, cando isto endexamais ocorre. A voz do autor implícito aparece decote ao longo da obra, mais nunca se mestura ou confunde coa voz das personaxes, senón que se distingue dela perfectamente a través do emprego de recursos gráficos, tipográficos ou ortográficos específicos, é dicir, ben mediante o uso de letra cursiva ou ben mediante a introdución entre parénteses das súas intervencións. O único caso da obra no que a voz do autor implícito non se marca con algún destes mecanismos é o poema introdutorio, que, de todos os xeitos, está xa claramente marcado no libro pola súa situación espacial, xa que se localiza, case a xeito de paratexto, fóra do corpo principal da obra, entre a dedicatoria e as citas que preceden os poemas.

Por outra banda, o autor implícito asume ás veces a identidade dun compilador que engade datos ou comenta con ironía os testemuños ofrecidos polas personaxes, pese a que só nunha ocasión no libro se nomea como tal, despois do epitafio de Ambrose Bierce. Este poema presenta unha relevancia emblemática dentro da totalidade da obra, polo que se reproduce integramente:
(Se un pecha os ollos, aínda pode escoitar a descarga de fusilaría e o paso do pelotón pisando na grava).

Unha mañá, en México, vin unha tapia chea de furados nunha vila ocupada polo sol e a soidade; e esa tapia estaba pintada co meu nome.

"Fixen unha longa viaxe ata chegar a esta tapia" dixen entón para min. "Mais pagou a pena. Non é un bo lugar para quedar a vivir, pero é un bo lugar para quedarmos a morrer."

(Nota do compilador: A Ambrose Bierce chamábanlle "O home máis perverso de San Francisco". Adoitaba dicir: "a morte non é o final, aínda queda o preito pola herdanza" $e$ tamén: "a tumba é un lugar no que esperar a chegada do estudante de Medicina". Escribía unha malhumorada columna no Examiner $e$ ao cumprir os setenta anos, marchou a México coa fin de "evitar a posibilidade de caer polas escaleiras do soto". Coma un peregrino, repartiu as súas propiedades, visitou os lugares onde combatera na Guerra Civil -é dicir, os lugares onde non morrera- e cruzou o Río Grande un día de decembro para desaparecer sen deixar rastro). (77)

O texto reúne e encapsula as características principais do poemario. Desde un punto de vista temático, o epitafio conxuga a reflexión sobre a vida e a morte, e comunica o amor pola literatura e certas figuras senlleiras; desde unha perspectiva estilística, ofrece unha clara tendencia á narratividade, certo ton melancólico pero tamén humorístico e retranqueiro, así como un evidente culturalismo ${ }^{10}$. Ademais, amosa a complexidade xenolóxica e a concorrencia de múltiplas voces diferentes que se dá en Lapidario. Respecto a esta variedade polifónica, o poema ábrese cunha intervención do autor implícito, entre parénteses e en letra cursiva, segue coa voz da personaxe en primeira persoa e remata cunha extensa nota do compilador, tamén enfatizada graficamente coa cursiva e a marca parentética. Obsérvase así que tanto o autor implícito como o compilador

${ }^{10}$ En canto ao culturalismo de Lapidario, Manuel Rodríguez Alonso (2005) vencellouno coa tendencia culturalista presente na poesía galega da xeración dos oitenta. Pola contra, na miña opinión, a traxectoria literaria de Murado distínguese por posuír un selo ben persoal e por discorrer á marxe das dinámicas dos grupos poéticos dominantes no sistema. 
incorporan os seus comentarios e apostilas ao comezo e ao final do texto, estabelecendo un marco para a voz do protagonista e deste xeito completando o episodio que se narra no epitafio.

\section{CONCLUSIÓN}

En suma, Lapidario entronca cunha tradición xenérica ben definida e delimitada desde a Antigüidade clásica e con antecedentes literarios tanto no eido da literatura universal como no ámbito galego, como é o epitafio, pero presenta asemade elementos que encarnan unha ruptura co xénero devandito. A reinterpretación das convencións xenolóxicas que propón o poemario, de raigaña posmoderna, implica a súa difícil categorización, feito afortalado, ademais, pola incorporación ao texto poético de compoñentes procedentes da escrita académica, así como pola presenza de recursos narrativos e dramáticos. Estes elementos conforman unha rede plurixenérica na que Murado semella sentirse confortábel e que serve con funcionalidade os propósitos da obra. Ademais, Lapidario amosa outra característica da posmodernidade literaria: a multiplicidade de voces que ecoan nas súas páxinas. Á parte das declaracións e testemuños en primeira persoa das propias personaxes, trazo típico do xénero epitáfico, nalgúns textos interveñen outras voces como a do autor implícito e mais a do compilador. Polo tanto, a concorrencia polifónica e a complexidade xenolóxica constitúen as achegas principais dunha obra que, aínda así, non oculta os valores lúdicos e a vontade culturalista que xacen no seu cerne.

\section{REFERENCIAS BIBLIOGRÁFICAS}

Araguas, Vicente (2005): “Os epitafios de Miguel Anxo Murado", El Correo Gallego, "Correo das Culturas" 20/02/2005, p. 3.

Browning, Robert (2005): La licencia y el límite (trad. C. Jiménez Arribas). Barcelona: DVD.

CASAS, Arturo (1998): “Lírica difusa, ou xéneros en tempo indecoroso", Grial. Revista galega de cultura 140, pp. 667-689.

Cunqueiro, Álvaro (1991): Herba aquí ou acolá (ed. X. H. Costas González). Vigo: Galaxia.

Dobry, Edgardo (2006): "Browning, el nexo esencial", El País, "Babelia" 25/03/2006 (dispoñíbel: http://www.elpais.com).

Equipo Glifo (2003): Dicionario de termos literarios (E-H). Santiago de Compostela: Centro Ramón Piñeiro para a Investigación en Humanidades / Xunta de Galicia.

Eyré, Xosé M. (1996): “A literatura actual”, en A. Ansede Estraviz e C. Sánchez Iglesias (eds.), Historia da Literatura Galega. Vigo: ASPG/A Nosa Terra, pp. 1538-1568.

FERGuson, Frances (1977): Wordsworth: Language as Counterspirit. New Haven: Yale University Press.

Ferreiro, Celso Emilio (2004): Poesía galega completa (ed. R. Nicolás). Vigo: Xerais.

Forcadela, Manuel (1996): “A poesía de posguerra”, en A. Ansede Estraviz e C. Sánchez Iglesias (eds.), Historia da Literatura Galega. Vigo: ASPG/A Nosa Terra, pp. 1058-1088.

Franco, Camilo (2004): "Miguel-Anxo Murado volve á poesía narrativa coa edición de Lapidario", La Voz de Galicia 21/06/2004, p. 54.

González Fernández, Helena (ed.) (2001): A tribo das baleas. Poetas de arestora. Vigo: Xerais.

Hall, Dewey W. (2001): "Signs of the Dead: Epitaphs, Inscriptions, and the Discourse of the Self”, ELH 68/3, pp. 655-677.

Iglesia Alvariño, Aquilino (1991): Poesías (ed. L. Rodríguez Gómez). Vigo: Xerais. 
Lee Masters, Edgar (1974): Antología de Spoon River (trad. A. Girri). Barcelona: Barral.

Mills-CourTs, Karen (1990): Poetry as Epitaph: Representation and Poetic Language. Baton Rouge: Louisiana State University Press.

Murado, Miguel-Anxo (1985): Bestiario dos descontentos. Vigo: Xerais. Esquío. (1990): Lapidario dos heterodoxos. Ferrol: Sociedade de Cultura Valle-Inclán, Colección

- (1993): Memoria de derribos. Vigo: Galaxia.

_ (1994): A grande noite de Fiz. Vigo: Xerais.

- (1995): Historias peregrinas. Lugo: TrisTram.

- (2000): Ruido. Relatos de guerra. Vigo: Galaxia.

- (2001): Mércores de cinza. Vigo: Xerais.

(2004): Lapidario. Vigo: Xerais.

- (2007): O soño da febre. Vigo: Galaxia.

Pato, Chus (2000): m-Talá. Vigo: Xerais.

RÁBAdE Villar, María do Cebreiro (2003): “A alteridade na obra de Avilés. A representación de América e a subxectividade das mulleres", en C. Ferreiro e I. Pena (eds.), Congreso sobre Antón Avilés de Taramancos. Santiago de Compostela: Xunta de Galicia, pp. 71-88.

(2014): "Poesía y juramento: los monólogos dramáticos de Álvaro Cunqueiro", Revista Hispánica Moderna 67/1, pp. 37-53.

RodríGuez Alonso, Manuel (2005): “Lapidario. Miguel-Anxo Murado”, Galicia Información 22/09/2014. 